\title{
Marcin Serwiński
}

Wrocław University of Economics

e-mail: marcin.serwinski@ue.wroc.pl

ORCID: 0000-0002-4064-3938

\section{IDENTIFICATION OF THE OPTIMAL AUTOMOTIVE R\&D AREA IN THE CONTEXT OF IMPLEMENTING THE FOLLOW-THE-SUN STRATEGY - EMPIRICAL STUDY}

\author{
IDENTYFIKACJA OPTYMALNEGO OBSZARU B+R \\ SEKTORA MOTORYZACYJNEGO \\ W KONTEKŚCIE IMPLEMENTACJI STRATEGII \\ FOLLOW-THE-SUN - BADANIA EMPIRYCZNE
}

DOI: $10.15611 / \mathrm{pn} .2019 .7 .22$

JEL Classification: F23, L62, O32

Summary: The main objective of the article is to select an optimal R\&D area of the automotive sector in the context of the possibility of implementing the Follow-the-Sun (FTS) strategy. Empirical research covers three areas of R\&D of this sector, excluding the area of Software Development, which according to current literature is the only one in which the FTS strategy is applied. The research was conducted between January and August 2019. The spatial scope of the research covered six international automotive companies providing R\&D services in at least one of the three surveyed areas. Due to the innovativeness of the presented subject matter, the research part of the study was preceded by the necessary information on the FTS strategy itself. Its main objective is to further increase the pace of R\&D work by using project teams dispersed in distant time zones and capable of ensuring a 24-hour work cycle without the need to perform it at night.

Keywords: Follow-the-Sun, R\&D, automotive, time zones, time-to-market.

Streszczenie: Głównym celem artykułu jest wyłonienie optymalnego obszaru B+R sektora motoryzacyjnego w kontekście możliwości implementacji strategii Follow-the-Sun (FTS). Badania empiryczne obejmują trzy obszary B+R tego sektora, wykluczając obszar Software Development, będący według aktualnej literatury przedmiotu jedynym, w którym strategia FTS znajduje zastosowanie. Badania przeprowadzone zostały pomiędzy styczniem a sierpniem 2019 roku i objęły sześć międzynarodowych przedsiębiorstw sektora motoryzacyjnego świadczących usługi $\mathrm{B}+\mathrm{R}$ przynajmniej w jednym z trzech badanych obszarów. Z uwagi na innowacyjność przedstawianej tematyki część badawcza opracowania została poprzedzona niezbędnymi informacjami na temat samej strategii FTS. Jej głównym założeniem jest dalszy 
wzrost tempa prac $\mathrm{B}+\mathrm{R}$ z wykorzystaniem zespołów projektowych rozproszonych w odległych strefach czasowych oraz mogących zapewnić całodobowy cykl pracy bez konieczności wykonywania jej w nocy.

Słowa kluczowe: Follow-the-Sun, B+R, motoryzacja, strefy czasowe, time-to-market.

\section{Introduction}

Today's business objectives of global companies mean that the essence of the wellknown phrase "time is money" is taking on an unimaginable dimension. Many companies that design, develop, manufacture and sell their own products use this time in two seemingly different ways. This is perfectly illustrated by trends in the automotive sector, where companies, on the one hand, reduce time-to-market (TTM) and thus potential losses by, among others, reducing the unused capacity of knowledge workers. On the other hand, they maximize profits by shortening the product-lifecycle (PLC) through a series of actions leading to the fact that a customer who is pleased with the purchase of a new car relatively quickly considers it out-dated, going to the car showroom to get a new version of it. The area that allows to visualize, probably to the widest group of customers, the operation of the mechanism described above is the smartphone market. The vast majority of users had the opportunity to struggle with the limited functionality or limited battery life, and speed of operation of their smartphone, often after less than two years from the time of purchase. The first option is most often caused by the inability to update the software. The second, paradoxically, is associated with its update. Therefore, regardless of the type of scenario, the customer is forced to buy a new product. Unfortunately with the development of autonomous and electric vehicles, this mechanism seems to be increasingly spreading to the automotive sector.

Although this issue is not the main theme of this publication, it is its background due to the Follow-the-Sun (FTS) strategy described below and the related objectives, whose understanding and application is the subject of this article. The main objective of this strategy is to further increase the pace of $R \& D$ work using time zones to ensure a 24-hour work cycle without the need to work at night. However before proceeding with the description of further searches for areas and sources of improving efficiency, the author wants to assure the reader of the awareness of the potential consequences of chasing the eternal expectations of the market, such as: faster, cheaper, better. Therefore, the article presents some data and facts which, in the author's opinion, may serve as a basis for further considerations on the moral and ethical level of this pursuit. Their interpretation or evaluation is left to the reader.

While the production of cars in light of Industry 4.0 is still undergoing a significant increase in efficiency, the rate of their development seems to be inevitably reaching certain limits. Since 1990 the development time of motor vehicles has been systematically reduced by an average of six to seven months every four years 
[Wallentowitz et al. 2009, p. 30]. Similarly, in the last decade PLC has been reduced by nearly a half [Sabadka 2014, p. 252]. Undoubtedly, these successes can be attributed to the progress in the field of computer science and the digitization of design tools. However, based on the example of Germany, the accompanying - more than fourteenfold - increase in the number of days of sick leave, categorized under the term of burnout, over the period 2004-2017 [https://de.statista.com/statistik/ daten/studie/239869/umfrage/arbeitsunfaehigkeitstage-aufgrund-von-burn-outerkrankungen/] should make everyone wonder where is the limit and what is its price? An additional interesting fact is that the infamous list of the above described absences is headed by such German federal lands as Bayern and the closely following Baden-Wuerttemberg [https://www.welt.de/wirtschaft/article143774194/BKK-Atlaszeigt-duesteres-Potenzial-der-Depressionen.html\#cs-DWO-WI-Depressionjs-Laender-Aufm-jpg.jpg], which are the world leaders of the automotive sector and research and development centres [https://www.nzz.ch/wirtschaft/ein-bayer-imhimmel-weshalb-der-freistaat-wirtschaftlich-so-gut-dasteht-ld.1426719].

The essence of the relatively extensive introduction of this study is to illustrate how desirable in the automotive sector is the reduction of TTM, defined as the period from the concept phase until the product is available for use or sale [Smith, Reinersten 1991]. It is also the main objective of the application of the Follow-the-Sun strategy described in detail in the next section.

\section{Follow-the-Sun strategy and the purpose of the study}

Referring to the information related to the constant pursuit of shortening the TTM contained in the introduction, one of the more neutral solutions to accelerate R\&D work is the FTS strategy - at least in theory. It assumes the performance of designing work in a 24-hour shift system, but without the need to work at night. The location of individual R\&D units at the appropriate longitude of the globe enables the use of time zones to achieve a 24-hour work cycle. When a given location ends a standard working day, the tasks performed during that shift are forwarded to the next location where the "sun rises".

Analysis of the terminology of related strategies shows a significant dissonance even between the most popular strategies in the literature, which are Follow-the-Sun and Round-the-Clock [Serwiński 2019]. Both of them are often used alternately, but recent literature increasingly identifies the most significant differences between them in the following ways:

- Follow-the-Sun is about speed,

- Round-the-Clock is about 24-hour coverage [Carmel, Espinosa 2011], for example helpdesks.

A more detailed definition of the FTS strategy, which seems to reflect its essence most precisely in the available literature on the subject, is presented below. It is 
important to note that it served as the basis in the carried out empirical research, in which each of the respondents was familiarized with its contents:

FTS is a special case of Global Software Development (GSD). FTS means that software work is handed off every day from one development site to the next - many time zones away. The main benefit is the reduction in development duration. The exact definition says that Software Development (SD) FTS means satisfying all four of the criteria described below [Carmel et al. 2008, pp. 5-6]:

1. Production sites are far apart in time zones.

2. One of the main objectives is duration reduction/time-to-market reduction.

3. At every point of time there is only one site that owns the product. (We must specify this criterion in order to make the dependency unambiguous).

4. Hand-offs are conducted daily, where a hand-off is defined as a check-in of a work unit that the next site is dependent upon in order to continue. (We specify this in order to make the dependency unambiguous).

According to this definition, the FTS strategy is identified only with the GDS area. The results of the literature analysis presented in one of the latest publications: "Empirical evidence in Follow-the-Sun software development: A systematic mapping study" [Kroll et al. 2018, pp. 34-35] prove the correctness of the statement that FTS is a special case of GSD. Although the automotive sector has Software Development units in its R\&D area portfolio, there is no literature on the use of FTS strategies in the typical design work of this sector.

The first works concerning the adaptation of the FTS strategy in such areas are presented on the example of the Body in White (BiW) development in the publication: "The use of time zones in cooperation among R\&D units in the automotive sector" [Serwiński 2019]. In addition, it points to a number of new conditions that provide a solid basis for the assumptions that the adaptation of the FTS strategy among R\&D units of the automotive sector, other than SD, is becoming more and more realistic.

Empirical studies and their results presented later in the study are in a way a continuation of these works and a desire to verify the assumptions made in them. For this reason, the following objectives have been identified:

1. Main/scientific objective: from among the three researched $R \& D$ areas of the automotive sector, selecting the optimal one in the context of the possibility of implementing the FTS strategy.

2. Additional/methodical objective: verification of the research tool for the doctoral thesis.

The summary of the fulfilment of the above objectives reveals the last, fifth section of the article.

\section{Research methodology}

The research was conducted between January and August 2019. The spatial scope of the research covered six international automotive companies providing $R \& D$ services in at least one of the three surveyed areas. The survey was addressed to experienced 
managers ${ }^{1}$ of R\&D Front Offices located around the facilities of their customers which are Original Equipment Manufacturers (OEM) in high cost countries such as Germany and Austria. From those Front Offices some tasks are delegated to other Back Office locations. The types of surveyed areas, as well as the number of queries and responses received, are presented in the table below.

Table 1. Number of enquiries and responses in the surveyed R\&D areas of the automotive sector

\begin{tabular}{|l|c|c|l|}
\hline $\begin{array}{c}\text { Surveyed } \\
\text { area }\end{array}$ & $\begin{array}{c}\text { No of } \\
\text { queries }\end{array}$ & $\begin{array}{c}\text { No of } \\
\text { responses }^{\text {a }}\end{array}$ & \multicolumn{1}{c|}{ Area description } \\
\hline $\begin{array}{l}\text { Body in } \\
\text { White } \\
(B i W)\end{array}$ & 7 & 3 & $\begin{array}{l}\text { BiW is a complicated steel-structure including 300 500 sheets with } \\
\text { complex shape and are assembled by means of welding in a high } \\
\text { rhythm through 55 75 robotic work-stations [Dong et al. 2007]. }\end{array}$ \\
\hline $\begin{array}{l}\text { Interior } \\
(\text { INT) }\end{array}$ & 5 & 3 & $\begin{array}{l}\text { INT develops the proportions, shape, placement, and surfaces for } \\
\text { the instrument panel, seats, door trim panels, headliner, pillar trims, } \\
\text { etc. [https://en.wikipedia.org/wiki...]. }\end{array}$ \\
\hline $\begin{array}{l}\text { Harness } \\
\text { Design } \\
\text { (HD) }\end{array}$ & 4 & $3^{\text {b) }}$ & $\begin{array}{l}\text { HD is the interconnecting wiring in the vehicle for the transmitting } \\
\text { electrical power and signals in the electrical system [Pradhan 2011]. }\end{array}$ \\
\hline$\Sigma$ & 16 & 9 & \\
\hline
\end{tabular}

a) The number of answers means not only sending back the completed survey form, but also discussing it during individual categorised interviews with each of the representatives of particular areas; b) It was possible to obtain feedback from all four respondents of the Harness Design area, however, due to much more difficulty in obtaining a comparable number of responses from other areas, the fourth respondent was informed in advance that there was no need to complete the survey

Source: own study.

Striving to achieve the objectives described in Section 2 of this study revealed the need for repeated correction of the research method, in which three basic stages could be distinguished:

1. Developing a research survey and sending it to the first experts.

2. Conducting an expert panel to correct the survey.

3. Categorised interviews with experts based on a corrected survey.

Their exact process is described in subsections below.

\subsection{Developing a research survey and sending to the first experts}

The initial stage consisted in preparing a detailed research survey and reaching managers managing dispersed project teams. The first, pilot version of the survey was sent by e-mail to four experts who showed great interest in the subject matter and represented two of the three R\&D areas under analysis. A number of feedback questions were received, along with important suggestions for improving the survey form.

${ }^{1}$ In the study, managers are also called alternately: experts, employees, respondents and interviewees. 


\subsection{Conducting an expert panel to correct the survey}

The variety of interpretations of some of the questions contained in the original form, as well as the suggestions for improvements made by the respondents, initiated a two-hour expert panel using a video-conference. Due to the distance between the panel participants working in three locations several hundred kilometres away from each other, the traditional form of its implementation was practically impossible. However, the nature of the connection proved to be sufficient, offering not only visual contact with each of the participants, but also enabling joint corrections to be made among experts by sharing the researcher's desktop with the survey displayed in the background.

In this way, a detailed survey was sent out in stages to representatives of particular areas in order to obtain the same amount of feedback for each of them. Moreover, the essence of the research was to make the profile of experts belonging to each of the fields as coherent as possible. On the one hand, this assumption led to a more justified analysis of the results obtained through analogies, and on the other hand, it further limited the potential circle of the already highly narrowed group of respondents. The high level of detail and complexity of the research questions necessary to study the sublime characteristics of work in each of the studied areas revealed the first feedback from the respondents. Although to a much lesser extent, there were still some feedback questions about the interpretation of some points of the survey. Therefore, the final form developed during the expert panel did not manage to remove the dilemma between the temptation to further clarify individual questions and the fear of causing a potential decrease in the feedback received due to the time-consuming survey.

\subsection{Categorised interviews with experts based on a corrected survey}

In response to the constantly appearing questions from the respondents, another correction of the previously planned research method was introduced, without changing the last version of the form developed during the expert panel. It consisted in additional categorised interviews on the basis of a survey questionnaire completed in advance as reliably as possible. The survey questions were all closed using dropdown menu and categorized in three tables:

- personal questions $=8 \mathrm{x}$

- location related questions $=10 \mathrm{x}$

- questions according to FTS strategy $=4 \mathrm{x}$

In order not to discourage respondents, they were offered short individual interviews via video to summarise the provided results together. In practice, however, they lasted from 90 to even 150 minutes.

Due to the limited volume of this study, the author decided to present only the seven most important research questions of the second and third categories. The 
content of the questions and answers, together with the resulting conclusions, is presented in Section 4 of the article. In the case of questions in the first category, only their answers were presented, which served as a description of the group of respondents in the next section.

The ultimately developed research method turned out to be much more labourintensive, than the previously planned developing and sending of survey, in anticipation of unambiguous results. The extension of the research method by an expert panel and a categorised interview resulted however in a complete and mutual understanding of both the author's questions and the answers of all nine respondents. Another advantage was that the author obtained much more additional, important information that could serve as a basis for more detailed research on the described issues.

\subsection{Description of the group of respondents}

The group of respondents consisted of a total of nine managers, i.e. three for each area. Each area was represented by men from two different companies, aged over 36, with at least 11 years of experience in R\&D automotive sector. All but one had experience in managing both projects and staff. The BiW area was represented by experts from the Development Service Provider (DSP) profile companies only, while the Interior (INT) and Harness Design (HD) areas were fully represented by Automotive Supplier (AS) employees. The professional profiles of all experts were therefore very comparable. Therefore, the greatest attention during the interpretation of the research results in the next part of this article was focused on questions generating significant discrepancies in answers. Finding the reason for these discrepancies was to serve as the key to achieve the main objective of the article, which is to identify the optimal R\&D area in the context of the possibility of implementing the FTS strategy.

\section{Research results and conclusions}

This section reports the results from the research questions defined for this study.

\subsection{RQ1 - On average, for what period of time does a project team consist of three or more members who are working on the same project?}

The project teams of all managers of BiW and INT areas maintain their staffing level of three or more employees for a period of two to three years, while the teams of all HD managers maintain this staffing level for a period of more than five years. During the categorized interviews, the period was specified by each of the HD respondents for seven to eight years, as the survey form did not predict such a long existence of teams of any of the areas. Moreover, additional information was obtained to understand such a large difference between the responses of BIW and INT areas and the HD area. 
Currently, BiW construction is most often outsourced by OEMs to DSP. BiW project teams on the DSP side are characterized by their relatively fast personnel growth, followed by an equally fast decline. This usually happens in the third year of R\&D work related to the decreasing number of project tasks determined by the upcoming Start of Production (SOP). In the realities of BiW, entering the serial production stage means a negligible demand for the work of R\&D units, caused by too high costs of possible changes in the supporting structure of the car body. AS companies of this area are usually engaged only in the production of car body parts, rather than participating in R\&D works. Therefore, obtaining feedback from AS to maximize analogues of individual areas was practically impossible for BiW.

In the INT area, R\&D works are carried out by both DSP and larger AS-profile companies with their own R\&D offices. The characteristics of personnel growth of INT project teams and its decline take similar course to those of BiW, although their maximum size in the most labour-intensive phase of the project is on average half as large. Here, also in the third year of R\&D works, a few months before the SOP, the teams consist of less than three people.

The HD area, contrary to BiW and partly INT, is characterized by the fact that R\&D tasks are most often performed on the side of AS, not DSP. This is due to the need for close and best cooperation between the R\&D department and Production within the same enterprise. This is also due to the continuous optimization of the wiring harnesses, not only in the concept phase, but also between SOP and End of Production (EOP). Receiving an OEM order for AS for R\&D works and then for the serial production of a car's wiring harness results in the maintenance of project teams consisting of not only three, but even more than six members, for more than seven years.

The answers to the first research question are therefore clearly in favour of the $\mathrm{HD}$ area. Indeed, the simplest arithmetic shows that locating at least two project members in each of the three distant locations in time zones significantly increases the likelihood of ensuring the continuity of the 24-hour operation in the event of the absence of one of the employees. Nearly a three times longer period of existence of project teams of this area should significantly facilitate building a culture of highly structured project cooperation, which is essential for the functioning of the FTS strategy [Carmel 2013, p. 64]. Also, building trust, which cannot be achieved immediately [Schmid 2013, p. 127] may prove to be more realistic among employees of the HD area.

\subsection{RQ2 - What is the highest human resources level of the project team in its most demanding phase?}

The number of full-time project team employees in the most demanding phase of the project was as follows for particular areas:

$$
\mathrm{BiW}=23, \mathrm{INT}=11, \mathrm{HD}=29 .
$$


The highest value obtained for the HD area represents it as the optimal one again. The increased human resources level of the project teams should better justify the reasonableness of investing in building additional $R \& D$ offices in distant longitudes of the globe.

\subsection{RQ3 - What is the average percentage of project tasks delegated to the Back Office?}

The essence of the above question was an attempt to determine how the intracompany cooperation of the studied R\&D areas is currently shaped between their Front and Back Office structures. The average percentage of tasks delegated to other Back Office locations also showed the HD area as a favourite according to the following results:

$$
\mathrm{BiW}=37 \%, \mathrm{INT}=45 \%, \mathrm{HD}=55 \% .
$$

Individual interviews with experts allowed the author to complete the RQ3 question with questions closely related to it. They were supposed to reveal the objectives of delegating tasks depending on the geographical location of the offices cooperating in the project.

For the nearby Back Office of the EMEA area, the main objective of delegating tasks, common to all areas, was to reduce costs (eight out of nine cases). The second important reason was the satisfactory quality of their work and the good understanding between employees in the project.

For distant locations in the American and Asian regions, the delegation was most often dictated by the proximity of the production infrastructure within the surveyed companies or the proximity of the OEM facilities. However, there were also signs of a desire to use time zones in projects of one of the surveyed areas. Detailed information on this subject reveals the answers to question RQ5.

Practically all of the assumed objectives of delegating the tasks of individual enterprises, regardless of the distance between the cooperating locations, were successfully achieved.

\subsection{RQ4 - In which regions (Americas, Asia) does your company have units with the same competence profile as yours?}

The analysis of detailed answers revealed that both companies represented by HD area experts have at least one R\&D office with the same competence profile in all strategic regions, i.e. EMEA, Americas and Asia. The companies of the other two areas of BiW and INT are also characterized by the presence in the same time zones of the globe, but at a slightly lower intensity. Therefore it can be assumed that, although to a different extent, all areas have the infrastructural potential to implement the FTS strategy. 


\subsection{RQ5 - With units of which regions (Americas, Asia) is there a cooperation within the same project?}

The most frequent cooperation with locations of distant time zones has been identified in the HD area. This phenomenon was observed much less frequently in the INT area and almost never in BiW - only one expert cooperated with one distant location.

Moreover, the most important answers in the context of the objective of this study were also received from the HD area. Two experts signalled their willingness to use the potential of time zones, supported by their experience gained in cooperation through three locations of all strategic regions within the same project. These responses therefore strengthened the HD area on the position of the optimal area in the context of the described searches.

\subsection{RQ6 - Is it possible to implement FTS strategy in your R\&D area of the automotive sector?}

The table below presents very diverse answers to the above question:

Table 2. Expert opinions on the possibilities of implementing FTS in their area

\begin{tabular}{|l|c|c|c|}
\hline & BiW & INT & HD \\
\hline No of positive responses & 0 out of 3 & 1 out of 3 & 3 out of 3 \\
\hline
\end{tabular}

Source: own study.

However they are consistent with the results obtained in the previous questions, explaining the optimism of HD area experts in relation to the implementation of the FTS strategy.

\subsection{RQ7 - Is it possible to implement FTS strategy in other R\&D areas of the automotive sector?}

Optimistic not only in the context of the objectives of this study, but also in the context of the usefulness of further research on FTS in R\&D automotive turned out to be the $100 \%$ positive response of all experts to the question RQ7. Despite negative assessments of the possibility of FTS implementation in their own areas, they remain optimistic about the FTS strategy in other areas of the surveyed sector.

\subsection{Synthetic presentation of results}

In order to illustrate the survey results in a synthetic form of a network diagram, the answers to all questions were converted into percentages according to the following boundary conditions: 
RQ1. $100 \%$ for 7.5 years - the highest value indicated by one of the areas.

RQ2. $100 \%$ for a 29 -person project team - the highest human resources level in projects in one of the areas.

RQ3. $100 \%$ is a purely theoretical value that means delegating all tasks to the Back Office.

RQ4. 100\% means the existence of parallel units of the company in all the three strategic regions, for each of the three experts of a given area.

RQ5. 100\% means cooperation of three distant locations within the same project among all three experts of a given area.

RQ6 \& RQ7. 100\% means a positive response from all three experts in the area.

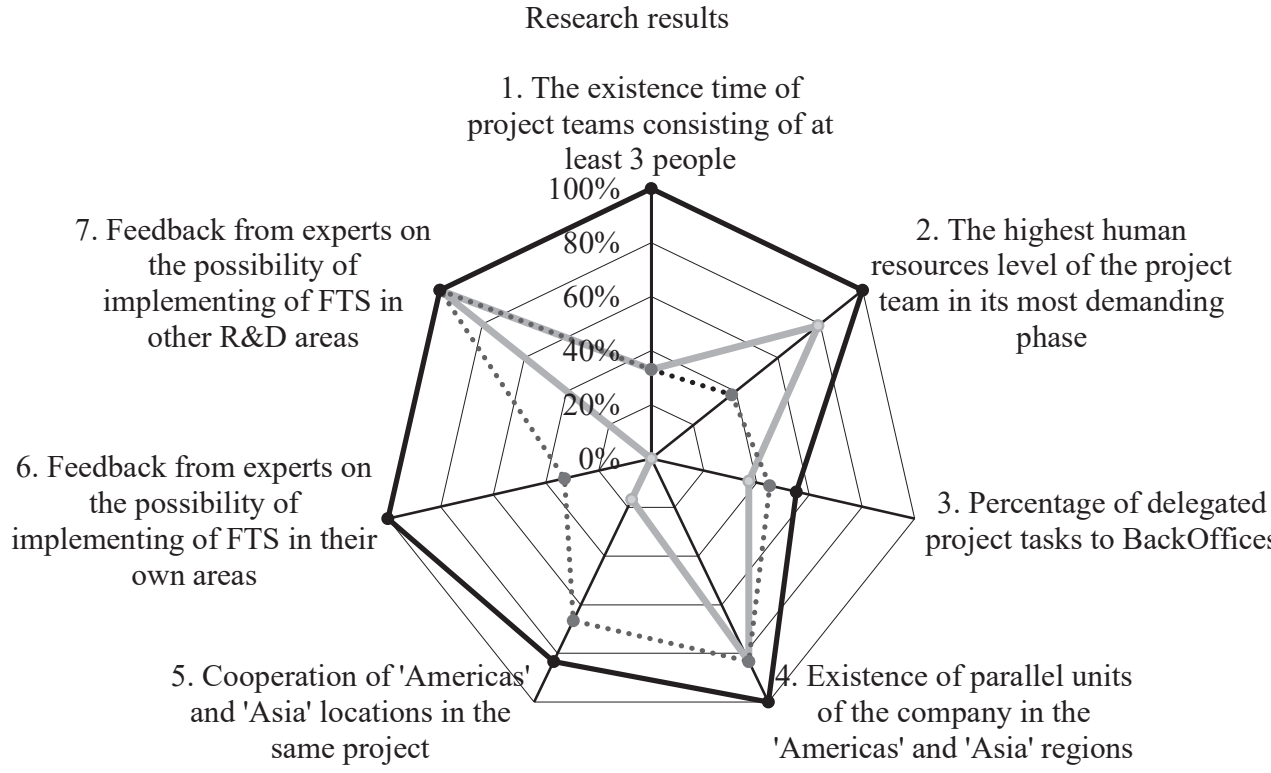

$\longrightarrow$ Body in White $[\mathrm{BiW}] \quad \ldots . \cdots$... Interior [INT] $\longrightarrow$ Harness Design $[\mathrm{HD}]$

Fig. 1. Diagram presenting the results of research in the categories 'location-related questions' and 'questions according to FTS strategy'

Source: own study.

The above form of illustrating the results clearly presents the HD area as optimal in the context of the described searches, at the same time being the realization of the main objective of the study. To learn more about the detailed analysis of the results and conclusions, return to points 4.1-4.7. 


\section{Conclusion}

Ultimately, the results obtained thanks to the repeated correction of the research methods made it possible to achieve the assumed objectives. It was possible to obtain feedback from managers of particular R\&D areas of the automotive sector and to verify and optimize the research tool for the doctoral thesis, thus fulfilling the additional, methodical objective of the study. Selection of the HD area as optimal in the context of FTS implementation was the culmination of the discussed research works and confirmed the usefulness of further research on this subject.

The strategic decision of VW from three years ago to build three new Volkswagen Group Future Centers in Silicon Valley, Potsdam and Beijing in which designers and digitalization experts work hand in hand to create the car of the future [Witter 2016] seems to confirm this usefulness. The HD area itself has much in common with SD, which is the only field of application of the FTS strategy according to the current literature on the subject. This fact, together with market expectations of the further reduction of TTM, resulted in the high interest of HD experts in the FTS subject which was in practice confirmed by the $100 \%$ of feedback from this area. In addition, the developing vehicle modular structure [Butz et al. 2014] should increase the interest in the FTS strategy due to the possibility of easier, SD-like, division of design tasks.

\section{Bibliography}

Butz M., Schmidt A., Tillmann G., 2014, Umbruch in der Automobilzuliefer-industrie: Standortoptimierung und Sourcing, Deloitte \& Touche GmbH Wirtschaftsprüfungsgesellschaft.

Carmel E., 2013, Overcoming your time zone challenges, IESE Insight, doi: 10.5581/002. ART-2317.

Carmel E., Dubinsky Y., Johnston J.M., 2008, Follow The Sun - Workflow In Global Software Development: Theory, Modeling And Quasi-Experiment To Explore Its Feasibility, Follow The Sun paper for Keystone conference printed on 5.09.2016, Keystone, Colorado, United States of America, https://auislandora.wrlc.org/islandora/object/auislandora\%3A53355/datastream/PDF/view.

Carmel E., Espinosa A., 2011, I'm Working While They're Sleeping: Time Zone Separation Challenges and Solutions, Nedder Stream Press, United States of America.

Dong W., Hui Li, Xiaoting T., 2007, Off-line programming of Spot-weld Robot for Car-body in White Based on Robcad, ICMA 2007, International Conference on Mechatronics and Automation, Harbin, China, pp. 763-768.

https://de.statista.com/statistik/daten/studie/239869/umfrage/arbeitsunfaehigkeitstage-aufgrund-vonburn-out-erkrankungen/ (02.08.2019).

https://en.wikipedia.org/wiki/Automotive_design\#Interior_design (08.10.2019).

https://www.welt.de/wirtschaft/article143774194/BKK-Atlas-zeigt-duesteres-Potenzial-der-Depressionen.html\#cs-DWO-WI-Depression-js-Laender-Aufm-jpg.jpg (02.08.2019).

https://www.nzz.ch/wirtschaft/ein-bayer-im-himmel-weshalb-der-freistaat-wirtschaftlich-so-gut-dasteht-ld.1426719 (02.08.2019).

Kroll J., Richardson I., Prikladnicki R., Audy J.L.N, 2018, Empirical evidence in follow the Sun software development: A systematic mapping study, Information and Software Technology, vol. 93. 
Pradhan A., 2011, Current Trends in Automotive Wire Harness Design, International Conference on Mechanical, Production and Automobile Engineering (ICMPAE’2011), Pattaya.

Sabadka D., 2014, Impacts of shortening product life cycle in the automotive industry, Technical University of Košice, Košice.

Schmid H., 2013, Barrieren im Wissenstransfer, Springer, Wiesbaden.

Serwiński M., 2019, Wykorzystanie stref czasowych we wspótpracy jednostek R\&D sektora automotive, [in:] P. Antonowicz, E. Malinowska, J. Siciński, Sektorowe uwarunkowania funkcjonowania i rozwoju przedsiębiorstw, Wydawnictwo Uniwersytetu Gdańskiego, Gdańsk.

Smith P.G., Reinersten D.G., 1991, Developing products in half the time, Van Nostrand Reinhold, New York.

Wallentowitz H., Freialdenhoven A., Olschewski I., 2009, Strategien in der Automobilindustrie: Technologietrends und Marktentwicklungen, Vieweg + Teubner, GWV Fachverlage GmbH, Wiesbaden.

Witter F., 2016, Volkswagen moving people, Investor Roadshow with Evercore ISI, New York and Boston. 